\title{
THE EFFECTIVENESS OF MOOD, UNDERSTANDING, RECALLING, DETECTING, ELABORATING, AND REVIEWING (MURDER) IN TEACHING READING VIEWED FROM STUDENTS' MOTIVATION ${ }^{1}$
}

\author{
Rengganis Siwi Amumpuni \\ E-mail: rengganis_kiswanto@yahoo.com
}

\begin{abstract}
The research was conducted at the first grade of English Teaching Department Madiun in the academic year of 2012/2013. The research method was quasi experimental research. The population in this research was the first grade students of English Teaching Department of IKIP PGRI Madiun. The writer used cluster random sampling to get the sample. The sample consists of 70 students which are divided into two classes, IA consisting 35 students as a control class and IB consisting 35 students as an experimental class. The instruments used to collect the data were reading test to get the score of reading skill and questionnaire to get the score of students' motivation. Before the instruments were used, the tryout was done to know the validity and reliability of instruments. The writer analyzed the data in term of their frequency distribution, normality, and homogeneity. Then, the data were analyzed by using multifactoral analysis $2 \mathrm{X} 2$, then followed by Tukey test. The findings in this research lead to some conclusions: (1) MURDER is more effective than DM for teaching reading; (2) The students having high motivation have better reading skill than the students having low motivation; and (3) There is an interaction between teaching methods and students' motivation for teaching reading. MURDER is suitable for students having high motivation and DM is suitable for students having low motivation.
\end{abstract}

Key words: Teaching Reading, MURDER, DM, Students' Motivation

\section{INTRODUCTION}

In this research, the writer focuses on the two teaching methods, Mood, Understanding, Recalling, Detecting, Elaborating, And Reviewing (MURDER) and Direct Method (DM). First, both teaching methods are applicable to be used in University. Second, both of them share different perspective and principles in teaching reading. The writer conducts an experimental research to investigate the effectiveness of MURDER (compared with DM) in teaching reading viewed from students' motivation. MURDER is used as the independent variable in experimental group, whereas DM is in control group. Meanwhile, reading skill is placed as the dependent variable.

This research is to find out the difference of both teaching methods and which one is more effective in teaching reading. Furthermore, the writer considers students' motivation as simple effect to find out whether MURDER and DM are suitable for students who have high or low motivation.

The purposes of the research are: (1) to prove whether MURDER is more effective than DM to teach reading; (2) to prove out whether the students having high motivation have better reading skill

\footnotetext{
${ }^{1}$ Research article.
} 
than those having low motivation; and (3) to prove out whether there is any interaction between teaching methods and students' motivation to teach reading.

Reading is one of the important elements in language that must be mastered by the learners. For students, reading is important because it can accelerate them in process of learning the target language. According to Abraham (1994: 6), in the early stages of a course towards oral proficiency, reading serves a variety of pedagogical purpose. The consideration strongly suggests that teachers can make good use of reading as part of an integrated skills approach to language learning. In other words, it can be said that reading is an act of communication, which takes place between the writer and the reader, as a way of sharing observation, conveying a massage, sharing information, expressing thoughts or ideas by using words that have been selected and put together in certain rules and conventions.

Reading comprehension is the core of reading activity. It shows that an influential factor in determining the success of reading process is comprehending a text in order to convey the meaning. Martin (2000:14) argues that reading comprehension is the process of 'constructing meaning' from a text. Wiener (1998: 7) states that efficient reading requires the ability to guess the meaning of unfamiliar words by using context (context refers to the sentence or paragraph in which a word occurs ). Reading skill is ability to understand a text and to get the meaning from the text. It involves the ability to find main ideas, find specific information, make inferences, and predict word meanings from context.

There are so many factors influencing teaching and learning reading. Some of them are teaching methods and students' motivation. In order to make the teaching reading successful, the teacher should use challenging and suitable teaching method. Here, the researcher proposes the use of Mood, Understanding, Recalling, Detecting, Elaborating, Reviewing (MURDER) as a method in teaching reading. MURDER is an instructional method centered on the learner. Hedge as quoted by Backett and Slater (2005: 108) states that MURDER was introduced into English as a second language (ESL) education as one way to reflect the principles of student-centered teaching. MURDER Method is one of the variants of script cooperation which involves the interaction between two partners learning from a text (Larson, et al,1995: 10). MURDER Method will give the students time to practice the target language and to reflect themselves. According to Raphael (2006: 10), MURDER method is a method for teaching reading comprehension to accomplish the task of reading text. It covers the indicators of reading skill because the students are required to generate some points about the provided text based on the reading comprehension. MURDER method also encourage the students to be active and to be efficient reader.

The sequencing of the activities in MURDER method are: first, the students are asked to work with their partners, both partners have to read the passage. Next, learner A summarizes the text and learners $\mathrm{B}$ tries to detect and correct misconception and identify omissions. Then, the learning partners elaborate the text content to make it more memorable. They can accomplish this by 
connecting the information with their own prior knowledge, for example by drawing comparisons or links to other topics. These roles are switched several times during the learning process. The establishment of the ability to read for the students is necessary to develop through MURDER method. This method is expected to raise the students' interest, motivation, and self-esteem to read.

In reading skill, MURDER will drive students to be more active in doing their reading activity. Through this method, the students are given the assignment in comprehending, reacalling activity based upon the result of the diagnosis of students' language errors in reading. The teacher will become facilitator in the class where the students will be the center of the teaching and learning process.

On the other hands, Direct Method is a conventional teaching method that helps students to learn basic skill and knowledge that can be taught in step by step fashion (Arends, 2009: 296). It is teacher-centered method which is skills-oriented and implies to the teacher-directed and teacher's guide. It means that the teaching process may include the teacher signaling, modeling, and following a lesson which is scripted and is designed to have the students respond chorally as the teacher signals the small group or an entire group of students. The Students just become the followers and depend on the teacher during the teaching learning process. Usually, the teacher asks the students to read the text, asks the difficult word, and then asks the students to translate the text. In applying DM to teach reading, first, the teacher gains students' attention and explains the topic, goal, and background information of the lesson. Then, the teacher explains all about the text they will learn and the way to produce it clearly. The teacher presents step-by-step information and demonstrates the skill correctly. Next, guided practice which involves an opportunity for the student to make a task under the teacher's guidance. Then, each student try to answer a text individually, while the teacher monitors progress and provides guidance. Furthermore, the teacher checks the students' answer. Then, the teacher gives comment, advice, and correction to the students.

Another factor influencing teaching and learning reading is students' motivation. Motivation is one of the important factors in the success of teaching and learning process. Ausubel (2000) argue that motivation is important because it determines the extent of learner's active involvement and attitude toward learning. William and Burden state that if asked to identify the most powerful influences on learning, motivation would probably be high on most teacher's list (1997: 111). There are extrinsic and intrinsic motivation. Extrinsic motivation stimulates students to engage in classroom activities effortly because completing these activity successfully will bring them valued rewards (Durkin, 1993:126) and he adds that instrinsic motivation applies students value to participate in the activity, and emphasizes on students interest in engaging these activity willingly. Students' motivation can be generated through many ways. It can derive from teacher, the students themselves, and their environment. If the teacher knows that his/ her students have low motivation, teacher has to find strategies to arouse the students' motivation to learn. Students' high motivation will enable the 
students to achieve good result and mental in learning. Every individual has different motivation, therefore, the teacher should be able to assist them generate their motivation.

In terms of education, motivation is an essential element necessary for learning. Motivation is an important element in relation to education and societal growth. Learning a foreign language is different from learning other subjects, mainly because of the social nature such as venture (William and Burden, 1997: 115). Tucker and Lumbert in Smith (1991:179) consider teacher's attitudes even more important than parental or community in influencing the outcome of instructed Second Language Acquisition. Teacher's attitude towards learners, surely can also effect the quality and quantity of learning which takes place (Smith, 1991:179).

Extrinsic motivation stimulates students to engage in classroom activities effortfully because completing these activity successfully will bring them valued rewards (Durkin, 1998:126) and he adds that instrinsic motivation applies students value to participate in the activity, and emphasizes on students interest in engaging these activity willingly. Motivation in learning refers to the power or the energy of the students for achieving the objectives of learning and mastery of language. This energy can be from inside (intrinsic) and outside (extrinsic). Intrinsic motivation, covers: (a) students are serious and dilligent in learning English; (b) students are interested in learning that language; (c) students are more active in the teaching and learning process; and (d) they are independent in leartning English. Extrinsic motivation motivation, covers: (a) the method (its used by the teacher in the teaching and learning process; (b) the influence from their friends; (c) to compete with their classmate; (d) it is supported by their parents/ family; and (e) team (group) and media. The different needs of students can influence them in motivating themselves in learning L2/ FL.

\section{RESEARCH METHODOLOGY}

The population of the research was the first grade students of English Teaching Department of IKIP PGRI Madiun which consisted of 200 students coming from seven classes. The sample, two classes which consisted of 70 students, was taken by using cluster random sampling. The sample was divided in two groups, experimental and control group. The experimental group was taught using Mood, Understanding, Recalling, Detecting, Elaborating, Reviewing (MURDER), while the control group was taught using Direct Method (DM). In collecting the data, reading test and motivation questionaire were used. Before the instruments were used, a try out was done to know the validity and reliability of instruments. In analyzing the data, the writer used a descriptive analysis and inferential analysis in this research. Descriptive analysis was used to know the mean, median, mode, and standard deviation of scores of the reading test. Meanwhile, inferential analysis was used to test the research hypotheses. Inferential analysis used was ANOVA and continued with Tukey Test. Before conducting ANOVA, normality and homogeneity test were done to check normality and homogeneity data. 


\section{THE RESULT OF THE RESEARCH}

Based on the result of the hypotheses testing, the research findings are as follows: (1) MURDER is more effective than DM in teaching reading ; (2) The students having high motivation have better reading skill than those having low motivation ; (3) There is an interaction between teaching methods and motivation toward students' reading skill.

\section{THE DISCUSSION OF THE RESULT STUDY}

According to the research findings, it can be said that MURDER is more effective than DM in teaching reading. MURDER is a student-centered teaching method that is designed to enhance initial learning and transfer to individual tasks by prescribing the nature and sequences of activities in which a cooperative pair of students should engage. This method will give the students time to practice the target language and to reflect themselves. The students are required to generate some points about provided text based on the reading comprehension. The students will be very active, busy, and challenged to find information and give their own opinion or ideas to solve or finish the task given. It also encourages the students to be active and to be efficient reader.

On the other hand, DM is teacher-centered and makes students become dependent. They wait for the teacher's explanation and instruction in the reading class. It facilitates success through instruction, translating, on going guidance, and support. Through instruction and translation, teacher provides the context of learning. Teacher guides and supports the students in their phases of learning material through comment, reinforcement, or question. In addition, the DM gives the students less opportunity to be active and creative.Therefore, it can be assumed that teaching reading by using MURDER method is more effective than DM

Based on the elaboration above, the difference between MURDER and DM can be seen from the learning activities done and the reading process. The teacher, in MURDER, is a facilitator while in DM the teacher has the main task to give stimulus to the students so that the students can begin to write toward the stimulus. Without the stimulus from the teacher, it is difficult for the students to do reading. In conclusion, the MURDER is more effective than DM in teaching reading.

The students who have high motivation have better reading skill than those who have low motivation. Students' motivation is one of the important aspects of reading process. If students have high motivation, of course, they are serious and dilligent, interested in learning, more active, independent in learning.. They know what they can do well and know how they can improve themselves.

On the contrary, students with low motivation have less progress in doing something. The students have low motivation, their reading comprehension is lower than the students who have high motivation because they are lazy to study. They don't have ambition to achieve good proficiency. Otherwise, the students who have low motivation will have difficulty in understanding the text given because they never try to find the solution. They will comprehend the text dependently to the 
teacher's instruction and translation. They have low desire to learn and very passive. Therefore, it can be assumed that the students having high motivation have better reading comprehension than those who have low motivation.

There is an interaction between teaching methods and students' motivation in teaching reading. Some teaching methods are necessary to high motivation students. One of them is MURDER method. MURDER is designed to enhance initial learning and transfer to individual tasks by prescribing the nature and sequences of activities in which a cooperative pair of students should engage. This method will put teacher as a facilitator, organizer, and consultant to students engaged in reading lesson. It also lets students to be more active. This method will be used very effectively for the students who have high motivation. By having high motivation, students will be more motivated and interested in doing their tasks. The students will be very active, busy, and challenged to find information and give their own opinion or ideas to solve or finish the task given. This method is not only concerned with teaching academic content but also considered to make the students develop their social and human relation with other students.

Meanwhile, DM does not give many opportunities to students to be active in comprehending the text. Teacher is the supplier of ideas to the students. This method does not promote achievement in creative thinking. This method will be more effective if it is used for the students who have low motivation. The students with low motivation are considered as non-active students. They do not have high motivation or interest to do their tasks. The student centrality no longer happens in this model. They depend on the teacher.

Finally, it can be assumed that MURDER method is appropriate in teaching reading for the students having high motivation than for those who have low motivation. Meanwhile, MURDER method is appropriate in teaching reading for the students having low motivation than for students having high motivation. Therefore, it is assumed that there is an interaction between teaching methods applied by teachers and students' motivation in teaching reading.

\section{CONCLUSION AND SUGGESTION}

Based on the research findings, it can be concluded that the use of MURDER in teaching reading is more effective than DM and there is an interaction between teaching methods and students' motivation in teaching reading. MURDER is more effective to teach reading for students having high motivation, whereas, DM is more effective to teach reading for students having low motivation. Therefore, it can be said that there is an interaction between teaching methods applied by teachers and students' motivation in teaching reading. In other words, the effectiveness of teaching methods depends on the degree of students' motivation.

Based on the research findings, the writer would like to propose some suggestions. First, in teaching, the teacher should be able to take every chance for choosing and adopting various teaching methods. Besides, the teacher should also consider about students' characteristics and psychological 
factors. This is very important, so the teacher can apply appropriate teaching methods, materials, and techniques by considering students' characteristics. In teaching reading, especially based on their degree of motivation, the teacher can apply MURDER to the students who have high motivation. For the low motivation students, the teacher can apply DM. Since there are students having high and low motivation placed in one class, the teacher should combine between two teaching methods which are appropriate with both of the degrees of students' motivation.

Second, the students should realize that they are the subject of learning, so they should be active and creative in doing all activities during the teaching and learning process. They should not consider their teacher as the only source for them to learn. They have to be active to look for some appropriate sources from internet, textbooks, magazines, etc. They need to study by themselves so that they become autonomous and active learners. In reading, if they are creative, they will have many ideas to get the best way for creating a good reading, so they can avoid being stuck.

Third, to the other researchers, the writer hopes that these research findings can be used as one of references for the future researches. This research is only the beginning for other's deep researches, it can be developed into wider point of view. Other researchers can look for the effectiveness of MURDER in teaching other skill such as speaking, listening, or writing and other psychological aspect such as students' risk-taking, self-esteem, learning interest, and so on. Hopefully, the further result of the research can support and complete this research.

\section{REFERENCES}

Abraham, Williard. 1994. A Time for Teaching. New York: Haper and Row Publisher. William, Marion .1997. Psychology for Language Teachers.Cambridge: Cambridge University Press.

Arrends, J. Richard. 1997. Classroom Instruction and Management. New York: The Mc Graw-Hill Company, Inc.

Ausubel,D.P. 2000. Educational Psychology . New York: Holt.

Brown, H. Douglas. 1987. Principles of Language Learning and Teaching. New Jersey: PrenticeHall, Inc.

Brown, H. Douglas. 2001. Teaching by Principles: An Interactive Approach to Language Pedagogy: $2^{\text {nd }}$ Edition. New York: Longman Inc.

DeBoer, John and Dallmann, Martha. 1964. The Teaching of Reading: Revised Edition. Holt, Rinehart \& Winston Inc.

Di Radio, Wendy. 2002. www.practical-philosophy.org.uk/volume5articles /motivation 
Durkin, D. 1993. Psychologycal Aspects in Teaching Learning Process. International Education Journal, 1993, 6(3), 272-280. Hannover: Shannon Research Press.

Elliot, Stephen. N. et al. 1999. Educational Psychology: Effective Teaching, Effective Learning. Singapore: Brown and Benchmark Publisher.

English Teaching Forum. Volume 44 Number 1. 2006

Fraenkel, Jak R and Wallen, Norman E. 1993. How to Design and Evaluate Research in Education: $2^{\text {nd }}$ Edition. Singapore: McGraw-Hill Book Co.

Harmer, Jeremy. 1998. The Practice of ELT. England: Longman Group.

Hartono, Rudi. 2005. Genres of Texts. Semarang: English Department, Faculty of Language and Art: Semarang State University.

Martin. 2000. Teaching Reading to ELF Learners. The Reading Matrix Vol 6 No 4, September. Retrieved from ELF Academic database

Mason, Emanuel J and Bramble, William J. 1997. Research in Education and the Behavioral Sciences: Concepts and Methods. Dubuque: Times Mirror Higher Education Group, Inc.

Minium, Edward. 1970. Statistical Reasoning in Psychology and Education. New York: John Wiley \& Sons, Inc.

Ngadiso. 2009. Modul Statistics. Universitas Sebelas Maret

Ormord, Jane Ellis. 2003. Educational Psychology: Developing Learners: $4^{\text {th }}$ edition. New Jersey: Merrill Prentice Hall.

Phillips, Deborah. 1994. Longman Practice Tests for the TOEFL. England. Longman Group.

Richards, Jack C, and Rodgers, Theodore S. 2003. Approaches and methods in Language Teaching. Cambridge: Cambridge University Press.

Richards, Jack C. 2002. Curriculum Development in Language Teaching. Cambridge: Cambridge University Press.

Smith and Dechant. 1991. Psikology in Teaching Reading. Prentice- Hall.

Wiener, Harvey S. 1978. Reading Skill Handbook .San Fransisco: Houghton Mifflin Company. 
